\title{
THE DEVELOPMENT OF A LOBURN FOOTHILL FARM
}

By. P. H. McGLOIN, Ç Linterbury Agricultural College,

This paper presents the story of the development of a farm in a foothills district, a district that achieved notoriety because of the number of abandoned farms in the middle and late thirties and the general low standard of productivity of the area. It is hoped also to show how applied farm management is the key to increased production.

The farm "Greybanks" is owned by Mr Geoffrey Harper. Its development commenced in the autumn of 1946.

The farm is in the north Loburn district on the banks of the Grey and Okuku Rivers,- some 12 miles north-west of Rangiora, the nearest centre and railhead. Whiterock limeworks lie 4 miles north of the farm.

\section{- DISTRICT}

The north Loburn district covers about 25 square miles. Production varies from apple growing to store sheep farming. It was one of the earlier settled areas in Canterbury and it was originally subdivided into holdings of 100 acres or less. The original cover has tussock and some manuka. It was extensively cropped with cereals until the original fertility gradually disappeared. Farms not readily sold were left unoccupied for periods until the mortgagors could sell them, and by the late thirties gorse had completely spread over some properties and scattered gorse appeared frequently near hedge lines. Today there are large areas still covered by gorse and farmed by the use of matches. However, many of the smaller holdings have been amalgamated and since the end of the Second World War considerable advances have been made: 


\section{CONCLUSION}

The browntop belt has been considered 'one of the problem areas of the South Island. It was an area that farmers with capital resources shunned with the result' that' it tended to be farmed by men of limited means. These farmers, although by no means lacking in effort, could not make progress and in fact even the financial men made little progress until after' the depression years, when with steadily rising prices they were able to apply the newly acquired knowledge of the use of improved pasture seed mixtures, including Certified white clover, and the regular use of superphosphate and lime, Nowadays these foothill farmers "have available one-man hay balers and modern silagemaking equipment, which make the provision of winter feed easy. Also there is now- an effective spray for spurrey, thus ensuring good establishment of root crops, and gorse can be controlled by a useful spray.

All these are revolutionising farming on the foothills and enabling substantial increases in sheep carrying to take place. The struggling farmers of the past are soundly established financial occupiers today. They still have problems, and one of them is that in the higher rainfall regions even with 'first-class pastures lamb fattening is difficult and unreliable. 


\section{THE FARM}

The farm is in two blocks. Block I is 334 acres and Block II, a mile away by road across the Grey River, is 166 acres, a total of 500 acres. The present area is made up of two and a half farms of the pre-thirties era. In 1946, 400 acres were freehold and 100 acres leasehold. In 1950 the leasehold area was freeholded together with another 60 acres which is under lease.

Half the farm is a clay loam with an average working season of 10 months. A quarter of the farm is poor clay loam with a working period often less than 6 months, and part of this has an iron pan. Of the remaining quarter, half is made up of big stone river terrace and the balance is swamp and poor river terrace. With the exception of some old river terraces and the swamp, the property is all flat and ploughable with a slight south-westerly aspect.

\section{CLIMATE}

The annual rainfall amounts to 35in. and can vary from about $20 \mathrm{in}$. to over $60 \mathrm{in}$. The rainfall pattern is usually late autumn-winter high with the lowest rainfall period usually in December to February. The farm lies just within the nor-west shower belt, but these rains are of little consequence. The high nor-west winds. which blow frequently can affect the yields of all crops, especially perennial ryegrass. Crop yields on several occasions have been reduced by hail damage, which can be bad about once in 7 years. Snow falls annually and falls of. a foot or more are not uncommon.

\section{LIMITATIONS}

The rainfall combined with the soil type, particularly in Block II, often makes cultivation difficult and sometimes impossible. Seepage can occur on Block II as a result of heavier rains on higher ground. On both blocks soil conditions can limit the sowing of autumn cereals and delay spring cultivation, and, if care is not taken, ploughing for winter fallowing can be 'missed by not starting early enough.

\section{CONDITION OF PROPERTY IN AUTUMN OF 1946}

The main utilisation was:-(see schedule attached).

100 acres in forage, new grass, fallow etc. 
100 acres in good pasture (all limed and topdressed).

250 acres in browntop, danthonia,' sweet vernal, gorse and moss.

The only cereal grown at that time was oats.

The chief weeds of economic importance were browntop, gorse, and fortunately only 20 acres of creeping fog.

The stocking .was just over 500 Corriedale 'ewes mated to Southdown and Corriedale rams.

The plant is listed on the accompanying chart and schedule.

\section{DEVELOPMENT PLAN}

Like all properties that require developing, there are certain limiting conditions. This fact is very important. You have so much pasture, good and bad, unimproved land, arable and non-arable, a flock of sheep to be fed, a range of implements, a labour force, and a supply of money for capital and working expenses. All these must be organised in such a way as to obtain the maximum number of the best production units over a period at the minimum cost.

This property, like others of its type, has three main management systems.. They are :-

A. Cropping, i.e. cereal and depletives.

B. Pasture.

$\mathrm{C} . \mathrm{S} \quad \mathrm{t} \quad \mathrm{o} \quad \mathrm{c} \quad \mathrm{k}$.

These management systems must be' organised so that they are completely integrated to produce maximum and continuous net returns and at the same time to improve the asset.

\section{A. CROP MANAGEMENT}

It was decided to crop to maximum on Block I in association, with maintenance of soil fertility and in conjunction with the proposed pasture renewal programme. Oats were grown at the start. The next crop grown was Research barley. Linseed was grown only once. Later wheat was introduced into the rotation and the basic rotation is:-

Old grass to preparatory crop, to. one. or two cereals, then to green feed oats, followed by a summer fallow and to new pasture (always drilled) ; e.g. rape, wheat, barley, greenfeed, summer fallow, and sow down, or 
Block ,I: rape, barley, barley, greenfeed, summer fal.. low, and sow down ;

- or rape, oats, oats, greenfeed, summer fallow; and $\mathrm{s}$ o w d o w n ;

. or turnips, barley, greenfeed, summer fallow, and ' $\mathrm{s}$ o w down. :

Block II: summer fallow, 'greenfeed, summer' fallow greenfeed, summer fallow to new grass.

. On, Block II two crops of oats have. been grown, this area being unsuitable for wheat.

Yields from all paddocks to date have reflected the paddock history and other factors influencing the yield have been timeliness, of cultivation, sowing dates, and weather at harvesting, e.g. high nor-west winds and hail.

The most important feature of the cropping programme was the amount of cash each crop provided; one of the essentials in any development project.

\section{B. PASTURE MANAGEMENT}

The most important management system of the three systems on: this property has undoubtedly been the pasture management system.

There were two features to this at the commencement of the development project and they were these:

-. 1. How to utilise the existing pasture on the property, which was 100 acres of good topdressed, and limed pasture and 250 acres of browntop, danthonia, gorse; etc.

2. 'The establishment of new areas of pasture.

. The first concern was the utilisation of existing gasture and how to manage the available good grass to the best advantage financially without impairing it in any way. In the autumn of ' 1946 all the good pasture was closed from grazing and the ewe flock was concentrated on the browntop and gorse areas. This allowed some late autumn growth to accumulate on the better pastures for' late winter 'and early spring grazing. Though it was April, this was the first outof-season grass saved,. a practice -that has been retained ever since and which in some years by skilful rationing has enabled sheep to be wintered without hay..'

The second concern is that eảch spring every grass farmer must: decide which. is the most-profitable avenue to-follow in vitilising his October. onwards sur- 
plus. He is guided by the expected net returns per acre and the reliability of the returns; here it is a matter of sheep versus small seeds. In the first year 43 acres of white clover were closed for seed and 23 acres of red clover, both areas being harvested. , The sheep numbers were not reduced on account of small seed harvesting, and throughout the period sheep numbers have never been reduced, but on occasions the amount of feed per sheep has been somewhat limited. The maxim was that on this country where fattening is usually difficult 6 forward stores are always better than 5 fats.

\section{NEW PASTURE}

Along with the utilisation of good pasture went the pasture renewal programme. Twenty-five acres of Pedigree perennial ryegrass and Pedigree white clover were 'drilled after a summer fallow in February of 1947. This was harvested for ryegrass seed in its first year, but the yield was at least halved, by a norwest gale. The year after white clover seed was harvested. Of importance here is the fact that this paddock was not grazed at all from the time it was drilled until after the white clover crop was harvested. This practice allows maximum seed production from the ryegrass and full tillering of white clover to take place followed by maximum seeding. This practice has been carried out with two exceptions (and then grazing was allowed for only a short period) with all newly sown paddocks. I believe that this feature has been the most important one in the farming practices used and had any of these pastures been grazed in their early life, our progress would not have been anything of note. By this method maximum seed production and cash returns have been- obtained and the resulting pastures have been outstanding after the second year.

Since 1947 the practice has been to sow new pasture on a summer fallow each- year, and to take ryegrass seed the first year and white clover in the second year without any grazing. Sometimes in the third year light grazing is done. Thereafter grazing takes priority on these fields. Small seeds have always come first and sheep second.

The pasture mixture sown each year has been 251b. of Pedigree or Government Stock perennial ryegrass and $2 \frac{1}{2}$ to $31 \mathrm{~b}$. of Pedigree white "clover.

From 1 to 2 tons of lime has been applied before sowing or duringthe first year of pasture's life and at 
least another ton during its life. Superphosphate (1 to $1 \frac{1}{2} \mathrm{cwt}$.) is drilled when sowing and the pasture receives 1 to $1 \frac{1}{d} \mathbf{c}$ t. per annum during its life. Today D.D.T. is used on each paddock. With all pasture management here the first concern was and is each paddock; it receives treatment according to its individ- . uality.

To summarise; the method of establishment, the mixture used, the topdressing, are the first features but of most importance has been each pasture's management and its utilisation, especially from October onwards. The aim of pasture management' on this farm has been accomplished; it was to save small seeds, to extend the area and the productive life of the pasture, and finally to carry more stock both during summer and winter.

\section{STOCK MANAGEMENT}

This brings us to the last management systemstock management.

Originally there were 500 odd ewes. Wool weights were just about 81 $1 \mathrm{lb}$. per ewe. Selling survival of lambs was 95 per cent. Lamb weights were 33 to $351 \mathrm{~b}$. with 20 to 30 per cent off the mothers, and the balance fattened on rape ; $2 / 3$ Southdown and $1 / 3$ Corriedale rams were used. Four-year ewes were purchased annually.

After two years the following "changes then took place. All the Corriedale rams were disposed of arid fat lamb sires used on all ewes. Some 2-tooth ewes and 4-year ewes were purchased and the following year all replacements were two-tooths. This has been carried out until 2 years ago, when in addition to the buying of 2-tooths, some ewe lambs have been purchased in the autumn also. The idea behind this is to have a small buffer of dry sheep should feed become scarce.

With the increase in carrying capacity:-

1. Wool weights have slightly increased and are now about 9lb.

2. Selling survival of lambs of 95 per cent has been maintain\&d.

3. Lamb weights are still 33 to $351 \mathrm{~b}$. with 35 per cent average off the mothers.

The increase from 25 -to 35 per cent of lambs fat off the mothers could be due to 100 per cent fat lamb sires. Individual returns per ewe are -practically the same, but this is of minor importance,, the yield per. 
acre being the goal. It has always been the aim' to stock to 'the hilt, but not overstock,. and should feed become scarce, the returns per acre are greater than from running slightly understocked.

The present carrying capacity is. over 800 ewes and over 100 other sheep plus 18 young cattle.

Winter feeding costs have been low. The three turnip crops grown were grown only to short-cut the rotation and they have all been only mediocre. About 10 acres of hay has been saved each year ; in- 2 years no hay was harvested at all. Qnly .10 tons of hay have been purchased in the last 7 years. Chief factor in the low cost of wintering has been the closing of, some pastures all through the autumn and the feeding of them during the winter and early spring, special care being taken in break feeding. The majority of the saved grass was kept until 2 months before lambing. Last season all the ryegrass straw was.. baled with the farm's own power take-off baler. All this was sold and the white clover straw was baled and retained. This winter some of this straw has been fed to the ewe flock and some to weaner 'run calves, the latter being fattened for the spring vealer trade;

The chart and schedule show how the flock has increased, though the available grazing area. is the same in 1947 and 1953. The carrying capacity has risen from 29 to $4 \frac{1}{2}$ ewes per acre, an increase of 80 per. cent.

It must not be thought that the development 'of the farm was done solely from farm profits. --The farm has always shown a profit, although much of each year's profit was usually spent in anticipation. Further bank -overdraft money was spent on additional 'live and dead stock. to facilitate progress. The overdraft was at its highest between the third and fourth year: During the fifth year it disappeared for a short time; and today it is non-existent. It is from this year (the seventh) that progress above the red line will be really achieved.

\section{CONCLUSION}

Good and improved pasture 'management is not sufficient en its own. It must be related in proportion to the other management systems for both crop and stock. These three management systems must be integrated to gain the maximum' from any farm imp r o v e m e $n$ t $s$ c $\mathrm{e}$ e. 


\section{SCHEDULES}

AREA OF PROPERTY * 1946-50

Block I: '234 acres freehold :-

100 acres leasehold

Block $11 \quad 166^{\prime}$ acres freehold

\section{0 acres}

$1950 \quad$ Block I 234 : acres freehold

161 acres freehold (61 subject to

lease).

Block II 166 acres freehold.
$5 \quad 6 \quad 1$
acres

UTILISATION: AUTUMN 1946.

100 acres of perennial ryegrass, and either white or red or sub. clovers. (one fifth of the farm!). 33 acres of new pasture, of which 18 acres proved a failure.

25 acres of greenfeed oats.

25 acres of forage stubble.

12 acres fallow ex browntop.

84 acres of browntop and some scattered gorse.

78 acres of danthonia dominant, sweet vernal, and

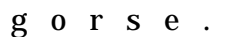

49 tires of gorse, moss, sweet vernal; and. some -browntop.

20 acres of creeping fog twitch.

30 acres of swamp.

20 acres of plantations, yards, house, etc.

and about 24 acres of shingle terraces in broom, gorse, etc.

500 acres

UTILISATION: AUTUMN 1952

260 acres of perennial ryegrass and white clover some subterranean clover.

33 acres new grass.

31 acres greenfeed oats.

37 acres forage stubble.

11 acres lucerne.

19 acres browntop.

30 acres danthonia dominant.

30 acres swamp.

25 acres plantations,.. yards, house; ;. etc.

19 acres shingle terraces in broom and gorse.

$500 \quad$ acres 


\section{CROP ACRES}

\begin{tabular}{|c|c|c|c|c|c|c|c|c|}
\hline & $/ 47$ & $47:-10$ & $48 / 49$ & $49 / 5$ & & $0 / 51 \quad 5$ & $51 / 52$ & $52 / 53$ \\
\hline Wheat & 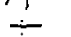 & .18 & $20: 13$ & 1 & & 23 & - & - \\
\hline Oats & 37 & & & 2 & & $\ldots$ & - & - \\
\hline Barley & - & 5 & 1 & 1 & & 21 & 49 & 45 \\
\hline Ryegrass & - & 25 & 28 & 4 & & 43 & 13 & 43 \\
\hline White Clover & 43 & 43 & 25 & 5 & & 37 & 62 & 31 \\
\hline Red clover & 23 & 10 & - & $=$ & & - & m & - \\
\hline Linseed & - & 26 & - & - & & - & $\longrightarrow$ & $m$ \\
\hline Rape & 38 & 20 & 13 & 2 & & 20 & 25 & 21 \\
\hline Turnips & $13:$ & 一 & - & & 8 & 12 & - & - \\
\hline S.F. N.G. & 25 & 28 & 59 & 4 & & 33 & 33 & 37 \\
\hline G.F. & - & 19 & 25 & 3 & & 6 & 8 & $一$ \\
\hline Hay meadow & 13 & 10 & 10 & - & & - & 10 & - \\
\hline Lucerne & - & - & - & - & & - & 11 & 1 \\
\hline Lupins, green & & & & & & & & \\
\hline $\begin{array}{l}\text { manure } \\
\text { Lucerne }\end{array}$ & $=$ & - & 6 & - & & 11 & 12 & 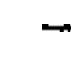 \\
\hline (new) & - & 一 & - & - & & 11 & - & 12 \\
\hline \multicolumn{9}{|c|}{ CROP YIELDS } \\
\hline \multirow{2}{*}{\multicolumn{2}{|c|}{ Wheat (bus.) }} & 1947 & 1948 & 1949 & 1950 & 1951 & 1952 & 1953 \\
\hline & & & & 43 & 22 & 45 & - & - \\
\hline \multirow{2}{*}{\multicolumn{2}{|c|}{$\begin{array}{l}\text { Oats (tons) } \\
\text { Barlev (bus.) }\end{array}$}} & $\overline{114}$ & $\overline{11}$ & $1 \frac{1}{2}$ & 3. & - & - & \\
\hline & & - & 46 & 56 & 72 & -51 & 50 & \\
\hline \multicolumn{2}{|c|}{ Ryegrass (bus.) } & - & 15 & 33 & 29 & 32 & 15 & \\
\hline \multirow{2}{*}{\multicolumn{2}{|c|}{ White clover (lb.) }} & 95 & 45 & 105 & 110 & 180 & 120 & \\
\hline \multirow{2}{*}{\multicolumn{2}{|c|}{$\begin{array}{l}\text { Red clover (lb.) } \\
\text { Linseed (cwt.) }\end{array}$}} & 70 & 40 & - & - & - & - & \\
\hline & & - & 43 & - & - & - & 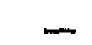 & \\
\hline
\end{tabular}

\section{PASTURE ACRES}

AVAILABLE GRAZING

October-January (inc.)

\begin{tabular}{|c|c|c|c|c|c|c|c|}
\hline & $46-47$ & $47-48$ & $48-49$ & $49-50$ & $50-51$ & $51-52$ & $52-53$ \\
\hline $\begin{array}{l}\text { Good } \\
\text { Fair }\end{array}$ & $\begin{array}{l}31 \\
76\end{array}$ & $\begin{array}{l}31 \\
68\end{array}$ & 68 & $\begin{array}{l}60 \\
70\end{array}$ & $\begin{array}{l}96 \\
58\end{array}$ & $\begin{array}{l}70 \\
66\end{array}$ & $\begin{array}{r}113 \\
48\end{array}$ \\
\hline $\begin{array}{l}\text { Browntop } \\
\text { and Gorse }\end{array}$ & 102 & 92 & 47 & 47 & 47 & 47 & 47 \\
\hline \multirow[t]{2}{*}{ TOTAL } & 209 & 181 & 179 & 177 & 201 & 183 & 208 \\
\hline & $46-47$ & $47-48$ & $48-49$ & $49-50$ & $50-51$ & 51-52 & $52-53$ \\
\hline $\begin{array}{l}\mathrm{E} \text { w e } \\
\text { Equivalents } \\
" n \text { per acre }\end{array}$ & $\begin{array}{l}525 \\
2.6\end{array}$ & $\begin{array}{r}525 \\
2.9\end{array}$ & $\begin{array}{c}640 \\
3.6 \\
158\end{array}$ & $\begin{array}{r}635 \\
3.6\end{array}$ & $\begin{array}{r}600 \\
3.0\end{array}$ & $\begin{array}{l}785 \\
4.3\end{array}$ & $\begin{array}{r}900 \\
4.5\end{array}$ \\
\hline
\end{tabular}


STOCK FIGURES

\begin{tabular}{|c|c|c|c|c|c|c|c|}
\hline & $46-47$ & $47-48$ & $48-49$ & $49-50$ & $50-51$ & $51-52$ & $52-53$ \\
\hline ewes & 504 & 522 & 616 & $: 620$ & 580 & 703 & 838 \\
\hline $\begin{array}{l}\text { odmess } \\
\text { ewe hoggets }\end{array}$ & 29 & 48 & 57 & 31 & 50 & $\begin{array}{l}10 \\
41 \\
83\end{array}$ & $\begin{array}{l}56 \\
56\end{array}$ \\
\hline
\end{tabular}

Cattle

vealers

$5 \quad 6-7$

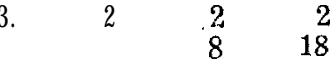

\section{FARM EQUIPMENT}

'Farm Machinery, Original

1, Tractor

1,3-f plough

1 , swamp plough

1 , single discs

1 , cultivator

1 , harrows

1 , drill

1 , roller

1 , binder

1. shearing plant

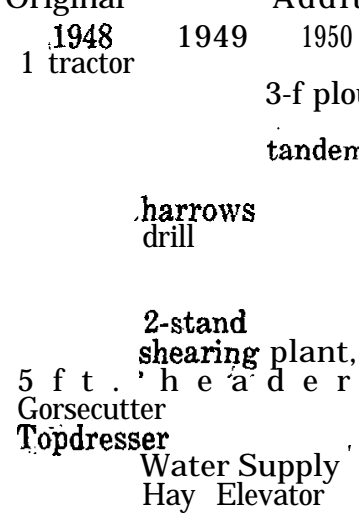

\section{Haybaler}

Siderake

Fencing includes remodelling repairs and new fences.

Buildings one house sold for removal, homestead and buildings altered.

Trees 5000 Pinus planted and fenced.

\section{DISCUSSION}

Q. I would like to know how Mr McGloin manages to get away with 2 years in which a paddock is ungrazed.

A. I must stress the low fertility of the area. In the first year (1946) of 33 acres of new grass 18 died without grazing owing to low fertility. If we had grazed on the other block, we would have got hardly any yield. The initial low fertility of this particular farm should be remembered.

Prof. Flay: This is the only type of farm on which this practice was successful. The production of small seeds has offered an opportunity of getting cash, I can call to mind many cases where no grazing has' given the seed so necessary for the economy of the farm. Quick, short returns 
are vital and were a most important feature on this particular farm.

Q. Now -that the vield is up to carrying $4 \frac{1}{2}$ sheep to the acre, does Mr McGloin intend to continue non-grazing?

A. We are not yet on 'our second time round. We have 1 paddock which in 2 years will be 'available for ploughing. Until the first round is finished there will be no alteration in the policy of not grazing.

Q. If the farm. is low in fertility, why was hay sold?

A. I said we sold some ryegrass straw. We should have bought in cattle and fed the ryegrass straw to them, but with the labour situation and available paddocks we couldn't do everything.

Q. Has nitrogen been used to encourage growth of grass and thus enable grazing?

A. This soil is just poor clay. It gets so fine and gets together that we just have spindly rye: 'If we apply sulphate of ammonia, we' only get seed and not much leaf. We wanted the cash. We have used sulphate of ammonia to $\mathrm{g}$ e $\mathrm{t} \mathrm{g} \mathrm{r}$ o w t h.

Q. If fertility was so low, why was the rotation formed to take two white crops in succession? I can't correlate the area of rape with the white crops. As we get further into the rotation I can, but in the first 3 years the area in rape does not equal the following year in cereals.

4. The area where we did the cropping in Block I was in good grass' when we went there, Some paddocks, owing to the high percentage of twitch, had to go back to rape. We had to leave a paddock out sometimes. 